\title{
Multidetector CT evaluation for the diagnosis of tracheal stenosis occurring shortly after intubation
}

\author{
Lisa Mizutani, ${ }^{1}$ Kazuyuki Yazawa, ${ }^{1}$ Yoshimichi Komatsu ${ }^{2}$
}

${ }^{1}$ Trauma and Critical Care Center, Suwa Red Cross Hospital, Suwa City, Nagano, Japan

${ }^{2}$ Department of Respiratory Medicine, Suwa Red Cross Hospital, Suwa City, Nagano, Japan

\section{Correspondence to}

Dr Kazuyuki Yazawa,

kazutora511@gmail.com
To cite: Mizutani L, Yazawa K, Komatsu Y. BMJ Case Reports Published online: 13 December 2012 doi:10.1136/bcr-2012007591

\section{DESCRIPTION}

A 22-year-old woman was admitted to our hospital because of loss of consciousness. She was seen ingesting excess schizophrenia medication following an argument. Twelve hours later, she was found unconscious and surrounded by vomit. Assessment on admission revealed: Glasgow Coma Score E1V1M4, temperature $38.4^{\circ} \mathrm{C}$ and pulse rate $135 \mathrm{bpm}$. She was severely underweight, with a body mass index of 15 . She was intubated without difficulty immediately after arrival using a $7 \mathrm{~mm}$ internal diameter endotracheal tube. Three days later, she was fully awake and was extubated uneventfully. Chest $\mathrm{x}$-rays revealed infiltrative shadows in both lungs. She was diagnosed with pneumonia and treated with antibiotics. She recovered uneventfully, and was discharged at 14 days after admission. Fourteen days after discharge, she returned because of hoarseness and dyspnoea with wheezing. She was treated for bronchial asthma, but her symptoms did not improve. Eleven days later, three-dimensional CT of the neck revealed hourglass-shaped tracheal stenosis with an internal diameter of $6 \mathrm{~mm}$ at the narrowest point, $5 \mathrm{~cm}$ distal to the glottis (figure 1). Virtual endoscopy showed concentric narrowing of the airway (figure 2). She was diagnosed with postintubation tracheal stenosis, and treated with balloon bronchoplasty and argon plasma coagulation. Figure 3 shows the tracheal stenosis via flexible tracheoscopy

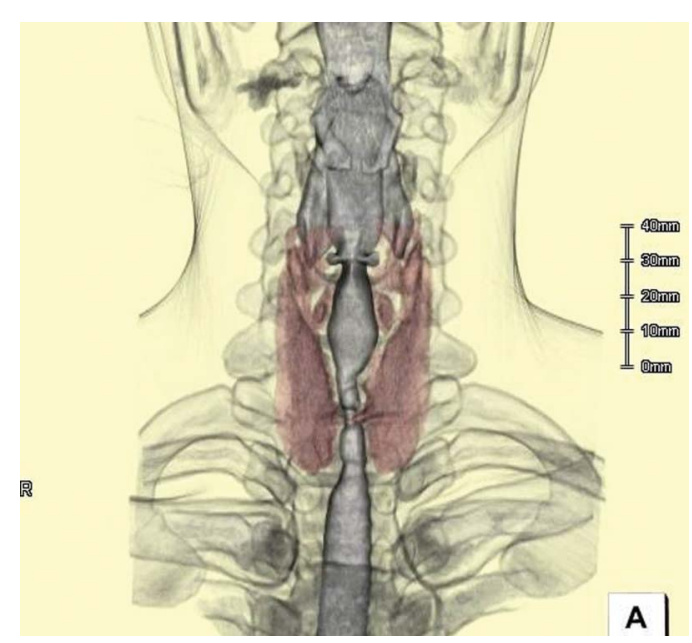

Figure 1 Three-dimensional CT showing hourglass-shaped tracheal stenosis with smallest diameter of $6 \mathrm{~mm}, 5 \mathrm{~cm}$ distal to the glottis.

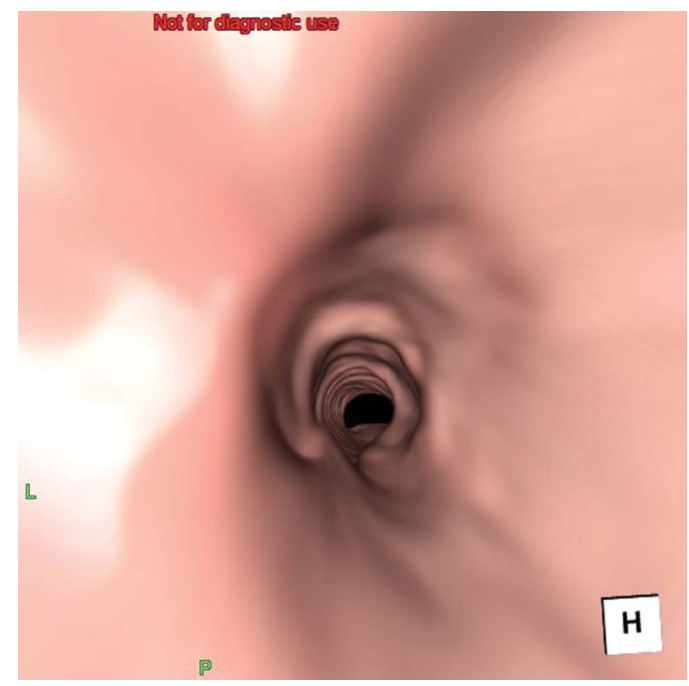

Figure 2 Virtual endoscopy showing concentric narrowing of the airway. View of proximal image of stenosis.

before treatment. Follow-up bronchoscopy showed marked improvement. Three months later, she presented again with dyspnoea and wheezing. She underwent repeat balloon bronchoplasty, and made a full recovery. The patient was subsequently lost to follow-up.

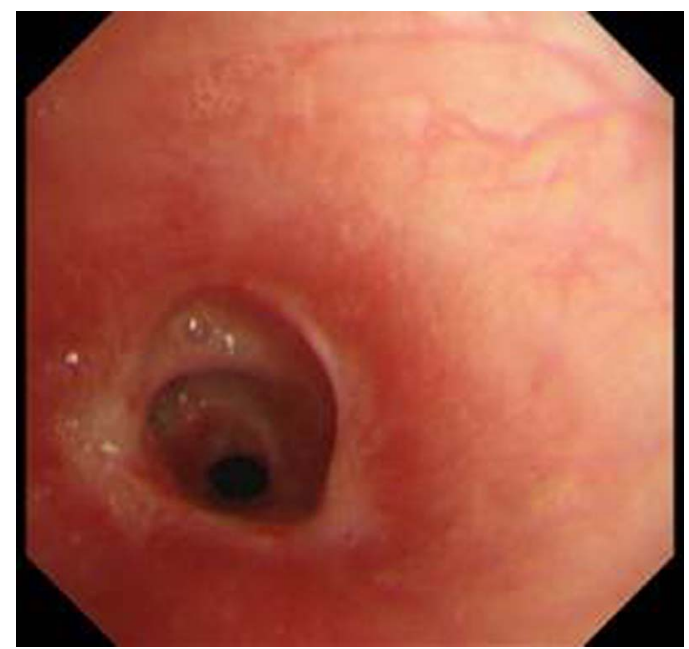

Figure 3 Flexible tracheoscopy view of the tracheal stenosis before the first dilation, showing similar features to the virtual endoscopy view. 


\section{Learning points}

- Postintubation tracheal stenosis is often misdiagnosed as bronchial asthma. ${ }^{1}$

- Three-dimensional CT is easy and useful in diagnosis and treatment planning in patients with tracheal stenosis. ${ }^{2}$
Competing interests None.

Patient consent Obtained.

Provenance and peer review Not commissioned; externally peer reviewed.

\section{REFERENCES}

1 Spittle N, McCluskey A. Tracheal stenosis after intubation. BMJ 2000;321:1000-2.

2 Morshed K, Trojanowska A, Szymariski M, et al. Evaluation of tracheal stenosis: comparison between computed tomography virtual tracheobronchoscopy with multiplannar reforming, flexible tracheofiberoscopy and intra-operative findings. Eur Arch Otorhinolaryngol 2011;268:591-7.

Copyright 2012 BMJ Publishing Group. All rights reserved. For permission to reuse any of this content visit http://group.bmj.com/group/rights-licensing/permissions.

BMJ Case Report Fellows may re-use this article for personal use and teaching without any further permission.

Become a Fellow of BMJ Case Reports today and you can:

- Submit as many cases as you like

- Enjoy fast sympathetic peer review and rapid publication of accepted articles

- Access all the published articles

- Re-use any of the published material for personal use and teaching without further permission

For information on Institutional Fellowships contact consortiasales@bmjgroup.com

Visit casereports.bmj.com for more articles like this and to become a Fellow 